\title{
AOR
}

Selected Papers of \#AolR2020:

The $21^{\text {st }}$ Annual Conference of the

Association of Internet Researchers

Virtual Event / 27-31 October 2020

\section{BAD ATTACHMENTS: EMAIL AND QUEER ANTI-CENSORSHIIP PROTESTS}

\author{
Cait McKinney \\ Simon Fraser University
}

This paper examines a 1996 U.S. internet censorship protest that encouraged users to email a series of technically "indecent" files as attachments to Speaker of the House Newt Gingrich using an online email generator. These attachments were: a list of abortion clinics, a graphic illustration of condom-use instructions, and excerpted sexually explicit scenes from Gingrich's own novel, 1945. Selecting from a drop-down menu, senders chose their attachments, completed a personalized message, and clicked send, all within a web-based form. By using the platform to inundate the Speaker's email with attachments, senders cleverly broke the censorship provisions of the 1996 Communications Decency Act (CDA), putting themselves at risk to the criminalization of sexual expression online.

The "bad attachments" protest grew out of the fact that online information about sexuality was vital to marginalized communities with limited access to other kinds of information channelsincluding queer and rural youth, and people living with HIV. I argue that the protest attachments constitute a queer, material digital practice, attuned to the political demand for ready information access as a means of survival. The research contributes to the conference theme of "Life" by approaching sexuality as a public and intimate mode of being in and working on digital networks (McGlotten 2013; Paasonen 2011). Methodologically, the paper draws on archival research in the collections of two LGBTQ community archives that document the bad attachment protest and its uptake on queer listservs; the paper supplements this archival research through the Internet Archive's Wayback Machine, which has allowed me to reconstruct how the protest functioned, and additional research in tech-related magazine and newspaper archives to understand the scale of the protest and its reception.

The CDA was the first legislation aimed at online content regulation in the United States, and reflected and reinforced emergent neoliberal understandings of sexuality, identity, and technology (Chun 2008; Gillespie 2018). The act defined and circumscribed sexual expression by barring the circulation of content that was "indecent" or "patently offensive" according to vague "community standards." These new regulations met significant protest by U.S. freedom of speech and civil liberties groups such as the American Civil Liberties Union and the Electronic Frontier Foundation, the porn industry, and also a range of sexual minority organizations invested in circulating information about sexuality online-from AIDS activists, to artists, to LGBT newsgroups and listservs, to niche kink subcultures, each of which depended on the web to communicate.

Suggested Citation (APA): McKinney, C. (2020, October). Bad Attachments: Email and Queer AntiCensorshiip Protests. Paper presented at AoIR 2020: The 21 th Annual Conference of the Association of Internet Researchers. Virtual Event: AolR. Retrieved from http://spir.aoir.org. 
Organized by an online free speech advocacy group called Interactivism, the attachment protest invited a range of actors from the constituencies listed above to mass email the politicians responsible for voting on and amending the CDA. The email that participants were invited to send to Gingrich read, in part, "Surely, we can keep children from pornography on the Internet without prohibiting adults from posting information or even discussing a whole range of subjects and issues. The CDA, which cannot be universally enforced, is likely to be selectively applied, possibly for political purposes." The CDA's indecency provision was successfully struck down through a court challenge in 1997, however the act continues to define the regulatory landscape for online sexual expression in the U.S. via controversial amendments such as FOSTA-SESTA (2018) and the Earn It Act (2020). As such, this paper provides necessary historical context to contemporary debates at the intersection of internet policy and sexuality and provides a potential model for queer response to conservative sexual regulation online (Duguay, Burgess and Suzor 2018).

This paper is one component of my larger research project on sexual minority counter-speech against the CDA. Here I am specifically interested in how this protest can help us to understand the material and political dimensions of email attachment as an emergent form. For example, news coverage of the protest emphasized the ease of a "flicked" keyboard, a "clicked" mouse, and a "pushed" send button as emerging digital modalities that were changing the nature of political response (c.f. Wired). A NetAction Notes bulletin from 1997 titled "Raising Hell with Email" similarly described a new era of mass participation in online protest made possible by email. This early excitement about clicktivism is complicated by attachments: these messages appended with sexually explicit files are instances where email attachments served as clandestine, "dirty" communication, once removed from the message itself, and a secondary aim of this research is to expand understandings of attachments and their materiality. Through attachments, stigmatized sex practices infiltrated everyday messaging and entangled sex with email. As media and internet scholars have argued, the promiscuity of networks were often explained through fears of vulnerability in sexual relationships (Chun and Friedland 2015; Helmreich 2000; Parikka 2007).

Though internet studies work on spam and net art has considered the potentially playful or aggravating affective dimensions of email in the 1990s, the attachment has been undertheorized in the field outside of computer virus transmission. I am interested in using this case to think about attachment as a spatial and temporal mode of communication that uses adjacency as a strategy for queer critique. Attachments are not messages themselves even if they are the primary reason for sending an email. But the circulation of attachments compels immediate distrust and invites a series of actions by receivers: email filters; institutional warnings to not open attachments from "untrusted" or "unknown" senders; and scanning for viruses. But downloading, clicking, and transferring the attachment to another program eventually reveals the substance of the attachment (previously known to the user only as a filename, size, and type). In the case of the email protest the attachment becomes a digital performative utterance (Butler 1997) as the law is broken once the tasks of opening are complete. These protest attachments draw on modalities of trouble, anticipation, play and sexual mischief to advance a resistant queer digital practice.

The paper puts forward a framework for thinking about email attachments as sociotechnical artefacts that pushed at the edges of emerging digital sex cultures in the United States. The paper is engaged with questions about web archives of sexuality, HIV's role in the history of internet regulation, and the ways sexuality materializes through digital networks. 


\section{References}

Butler, Judith. 1997. Excitable Speech: A Politics of the Performative. Routledge.

Chun, Wendy Hui Kyong. 2008. Control and Freedom: Power and Paranoia in the Age of Fiber Optics. MIT Press.

Chun, Wendy Hui Kyong, and Sarah Friedland. 2015. "Habits of Leaking: Of Sluts and Network Cards." Differences 26 (2): 1-28. https://doi.org/10.1215/10407391-3145937.

Duguay, Stefanie, Jean Burgess, and Nicolas Suzor. 2018. "Queer Women's Experiences of Patchwork Platform Governance on Tinder, Instagram, and Vine." Convergence 0 (0): 1354856518781530. https://doi.org/10.1177/1354856518781530.

Gillespie, Tarleton. 2018. Custodians of the Internet: Platforms, Content Moderation, and the Hidden Decisions That Shape Social Media. Yale University Press.

Helmreich, Stefan. 2000. "Flexible Infections: Computer Viruses, Human Bodies, Nation-States, Evolutionary Capitalism." Science, Technology, \& Human Values 25 (4): 472-91. https://doi.org/10.1177/016224390002500404.

McGlotten, Shaka. 2013. Virtual Intimacies: Media, Affect, and Queer Sociality. SUNY Press.

"NetAction Notes 18." n.d. Accessed February 28, 2020. https://www.netaction.org/notes/notes18.html.

Paasonen, Susanna. 2011. Carnal Resonance: Affect and Online Pornography. MIT Press.

Parikka, Jussi. 2007. Digital Contagions: A Media Archaeology of Computer Viruses. Peter Lang.

WIRED. 1996. "Net Surf." Wired, September 1, 1996. https://www.wired.com/1996/09/net-surf10/. 